\title{
HPLC-DAD PROFILE OF PHENOLIC COMPOUNDS, CYTOTOXICITY, ANTIOXIDANT AND ANTI-INFLAMMATORY ACTIVITIES OF THE AMAZON FRUIT Caryocar villosum
}

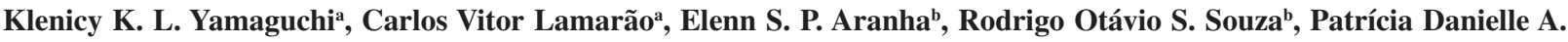 \\ Oliveira $^{\mathrm{b}}$, Marne C. Vasconcellos ${ }^{\mathrm{b}}$, Emerson S. Lima ${ }^{\mathrm{b}}$ and Valdir F. Veiga-Junior ${ }^{\mathrm{a}, *}$ \\ a'Departamento de Química, Instituto de Ciências Exatas, Universidade Federal do Amazonas, Setor Norte, Av. Rodrigo Octávio, \\ 6.200, Coroado, 69080-900 Manaus - AM, Brasil \\ ${ }^{b}$ Faculdade de Ciências Farmacêuticas, Universidade Federal do Amazonas, Setor Sul, Av. Rodrigo Octávio, 6.200, Coroado, \\ 69080-900, Manaus -AM, Brasil
}

Recebido em 08/11/2016; aceito em 31/01/2017; publicado na web em 24/03/2017

\begin{abstract}
Piquiá (Caryocar villosum - Caryocaraceae) is a native fruit from the Amazon region rich in bioactive substances. Fruit pulp extracts were analyzed by HPLC, together with extracts obtained from fruit pulp industry residual parts, byproducts such as husks (shells) and seeds. Extracts were prepared with two ethanolic solvent systems. Phenolic substances ellagic and gallic acids were detected with standards and quantified by HPLC. Cytotoxic, antioxidant and anti-inflammatory activities in vitro were also evaluated. Shell extracts showed free radicals scavenger capacity in ABTS $\left(\mathrm{IC}_{50}: 3.93 \pm 0.12 \mu \mathrm{g} \mathrm{mL}^{-1}\right)$ and DPPH models $\left(\mathrm{IC}_{50}: 7.81 \pm 0.34 \mu \mathrm{g} \mathrm{mL}\right.$ ), low cytotoxicity in human fibroblasts, but high at tumor strains, and also a high anti-inflammatory potential observed by the inhibition of nitric oxide production. At low concentrations $\left(20 \mu \mathrm{g} \mathrm{mL}^{-1}\right)$, excellent antioxidant activities were verified in cellular assays, with percentages of $70.69 \pm 2.77 \%, 79.89 \pm 6.50 \%$ and $79.48 \pm 8.6 \%$ for shell, pulp and seed extracts, respectively. With this set of results, C. villosum fruit extracts become a high potential raw material to be used in pharmaceutical and cosmetic applications.
\end{abstract}

Keywords: Amazon; Caryocar villosum; cell antioxidant assay; nitric oxide; fruit byproducts.

\section{INTRODUCTION}

The Amazon region stands out for its huge diversity of exotic fruits, with different biological and bioactive components. However, there are many fruits used by local people and explored only by regional industries but with no literature data regarding their chemical composition and biological properties. Caryocar villosum (Aubl.) Pers., Caryocaraceae, known as piquiá, is one of these almost unknown Amazonian native fruits, an unexplored biotechnological resource. Its edible oil is used to prepare regional dishes, replacing butter, for the manufacture of soaps, but also with other cosmetics applications. ${ }^{1}$ In French Guyana, pulp and peel are used as fish poison, ${ }^{2}$ property attributed to the presence of saponins. ${ }^{3}$

Previous studies have been shown that $C$. villosum is an important source of bioactive compounds. When compared to other 18 tropical fruits, piquiá showed the highest scores for total flavonoids and phenolic compounds, and also the highest antioxidant activity. ${ }^{4}$

Fruit pulp extracts were studied phytochemically and gallic, ellagic and ellagic rhamnoside acids were identified together with antheraxanthin and zeaxanthin. ${ }^{5,6}$ The fixed oil from the fruit pulp showed a topical antiinflammatory effect in rats, and its fatty acid methyl esters hexadecanoate, octadecanoate and $E$-octadecenoate were also correlated with such activity. ${ }^{7}$ Others pharmacological activities were already studied, such as genotoxicity and oxidative stress evaluation. ${ }^{89}$ More studied, pequi (Caryocar brasiliense Camb. / Cayocar coriaceum W.) is a similar Brazilian savanna fruit that showed anti-inflammatory, hypolipemic and healing activities on recently performed studies..$^{10,11}$

Between the paradigms of scientific research in the twenty-first century, the valorization of living resources has been gaining space. Two consequences of this view are the use of in vitro models to preliminary evaluation of biological activities (bioethical issues) and the full use of natural resources without generation of waste, the

*e-mail: valdir.veiga@gmail.com biorefinery concept. In vitro assays have been used as an important tool in the search for bioactive natural products, promoting efficient responses to the search of biological activities on extracts, such as antioxidant, anti-inflammatory and cytotoxic evaluation. The capacity to inhibit macrophage is one of these tests, with a central role in inflammatory diseases through the release of inflammatory mediators such as prostaglandin $\left(\mathrm{PGE}_{2}\right)$, nitric oxide $\left(\mathrm{NO}^{*}\right)$ and cytokines, involved in the immune response. ${ }^{12}$ Biorefineries, by its side, similarly to oil refineries, intends to promote the use of a natural resource in a rational and without waste way. To the fruit pulp industry, it means the use of all parts, from husks (exocarp) to seeds, not only mesocarps. Natural products chemistry can play an important role in this process, extracting bioactive molecules from these residues before they end with the conversion of cellulose in energy. They represent a cheap and useful raw materials to the development of organic processes. Our research group have been studying the chemistry, bioactivities (mainly in vitro) and biotechnology uses of Amazon species, such as sacaca (Croton cajucara Benth), ${ }^{13}$ copaiba (Copaifera sp. L.), ${ }^{14}$ and the native fruits. ${ }^{15}$ The combination of in vitro and in cell models is useful and contributes to the understanding of the possible mechanism of action.

Only one-off phytochemical and pharmacological studies were performed with Cayocar villosum, mainly with fruit pulp extracts. This study aims to initiate a wide research on this amazon natural resource, characterizing some of the main phenolic compounds from fruit pulp, seed and shell extracts (obtained by hydroethanolic solvents) by HPLC and also intends to evaluate their antioxidant activity, cytotoxic and anti-inflammatory potential.

\section{MATERIALS AND METHODS}

\section{Chemicals and reagents}

Trolox (6-hydroxy-2,5,7,8-tetramethylchroman-2caboxylic acid), $\alpha, \alpha$-diphenyl-picrylhadrazyl (DPPH), 
2,2'-azino-bis(3-ethylbenzothiazoline-6-sulphonic acid) (ABTS), gallic acid, ellagic acid, quercetin were obtained from SigmaAldrich (St. Louis, USA). Folin-Ciocalteu reagent was obtained from (Sigma-Aldrich Chemie, Steinheim, Germany). Extraction solvents used were ethanol and methanol (HPLC grade) obtained from Merck (Darmstadt, Germany). Water was obtained from the laboratory distillation system.

\section{Equipment}

Microplate reader DTX 800 multimode detector UV/Visible spectrophotometer, Beckman Coulter. HPLC (Shimatzu) analysis were performed on a C18 Synergi Hydro column $(4 \mu \mathrm{m}, 150 \mathrm{~mm}$ x $4.6 \mathrm{~mm}$, Phenomenex), using a with a $0.7 \mathrm{~mL} \mathrm{~min}^{-1}$ flow.

\section{Fruits}

The $C$. villosum fruits were collected and identified by Dr. Raquel Medeiros, in February 2012 at the Ducke Reserve. A voucher specimen (Registry $n^{\circ} 73164$ ) was deposited in the herbarium of the Instituto Nacional de Pesquisas da Amazônia (INPA), Manaus, Brazil. All ripe fruits were cut in half, and the shells manually removed from the pulp and seeds. The fruits were dried in an air circulation oven at $40{ }^{\circ} \mathrm{C}$ for 48 hours, and, then, crushed in a mill.

\section{C. villosum extracts preparation}

Shells, seeds and pulp powder $(50 \mathrm{~g})$ were extracted with ethanol $(500 \mathrm{~mL})$ and hydroethanolic solution (8:2 ethanol:water) separately at room temperature for $48 \mathrm{~h}$. The extracts were dried using a rotary evaporator with vacuum. The dried extracts were stored at $-20{ }^{\circ} \mathrm{C}$ until analyses.

\section{Total phenolic determination}

The total phenolic content was determined by Folin-Ciocalteu method. ${ }^{16}$ The extract solution $(10 \mu \mathrm{L})$ was mixed with $50 \mu \mathrm{L}$ of Folin-Ciocalteu reagent for $8 \mathrm{~min}$ and $240 \mu \mathrm{L}$ of sodium carbonate $\left(\mathrm{Na}_{2} \mathrm{CO}_{3}\right)$ was added. After incubation at room temperature for 3 $\mathrm{min}$, the absorbance of the reaction mixture was measured at $715 \mathrm{~nm}$ against a methanol blank, using a microplate reader. Gallic acid was used as standard. The experiments were performed in triplicate and the mean results determined. Data for the total phenolic content were expressed as gallic acid equivalents (mg GAE. $100 \mathrm{~g}^{-1} \mathrm{dw}$ ) of extract.

\section{Total flavonoids determination}

The total flavonoid content was determined with aluminum chloride colorimetric method, ${ }^{17}$ adapted for microplate. Each fruit extract ( $30 \mu \mathrm{g}$ of $1: 10 \mathrm{~g} \mathrm{~mL}^{-1}$ in DMSO) was individually added to a mixture with $90 \mu \mathrm{L}$ of ethanol, $6 \mu \mathrm{L}$ of $10 \%$ aluminum chloride, $6 \mu \mathrm{L}$ of $1 \mathrm{~mol} \mathrm{~L}^{-1}$ potassium acetate in $168 \mu \mathrm{L}$ of distilled water. It remained at room temperature for $30 \mathrm{~min}$; the absorbance of the reaction mixture was measured at $405 \mathrm{~nm}$ with a microplate reader. Data of the total flavonoids content in the dry matter was expressed as $\%$. All samples were analyzed in triplicates.

\section{HPLC Analysis}

Phenolic compounds were separated by HPLC with reversed phase system (column temperature set at $29^{\circ} \mathrm{C}$ ), using a linear gradient of water:formic acid (99.5:0.5, v/v) (solvent A) and acetonitrile:formic $\operatorname{acid}(99.5: 0.5, \mathrm{v} / \mathrm{v})($ solvent $\mathrm{B})$ as the mobile phase in gradient from
A:B 99:1 to 50:50 in $30 \mathrm{~min}$, then from 50:50 to $1: 99$ in $15 \mathrm{~min}$. This latest ratio (1:99) was maintained for an additional 5 min. ${ }^{6}$ Gallic and ellagic acids were quantified by comparison to external standards using six point analytical curves (each point tested in triplicate). In all cases, the $\mathrm{R}^{2}$ values were higher than 0.99 .

\section{Antioxidant Activity}

ABTS radical scavenging assay

The ABTS radical cation $\left(\mathrm{ABTS}^{\cdot+}\right)$ method, ${ }^{18}$ with some modification was conducted by reacting $7 \mathrm{mmol} \mathrm{L}^{-1}$ ABTS stock solution with $2.45 \mathrm{mmol} \mathrm{L}^{-1}$ potassium persulfate (final concentration) and allowing the mixture to stand in the dark at room temperature for $12-16 \mathrm{~h}$ before use. The $\mathrm{ABTS}^{*+}$ was diluted to the absorbance of $0.70 \pm 0.02$ and stored for off line and on line assays. $30 \mu \mathrm{L}$ of diluted extracts in different concentrations (1-100 $\left.\mu \mathrm{g} \mathrm{mL}^{-1}\right)$ were added with $270 \mu \mathrm{L}$ of $\mathrm{ABTS}^{-+}$solution and stand in dark at room temperature for $15 \mathrm{~min}$. The absorbance was measured at $630 \mathrm{~nm}$ with a microplate reader. All determinations were carried out in triplicate, for each concentration for both standard and samples. The percentage of absorbance inhibition at $630 \mathrm{~nm}$ was calculated and plotted as a function of concentration of antioxidants and Trolox ${ }^{\circledR}$, for the standard reference data.

\section{DPPH radical scavenging assay}

The DPPH radical scavenging activity, ${ }^{19}$ with slight modification, was performed using $30 \mu \mathrm{L}$ of extracts in different concentrations (1$100 \mu \mathrm{g} \mathrm{mL} \mathrm{m}^{-1} \mathrm{DMSO}$ ) and mixed with $270 \mu \mathrm{L}$ of DPPH in ethanol, on a 96-well plate. The plate was kept in the dark for $30 \mathrm{~min}$, after that the absorbance of the solution was measured at $517 \mathrm{~nm}$ in a microplate reader. Blanks (DMSO) and standards (quercetin solutions in DMSO) were run simultaneously. Extracts were first tested at a single concentration of $100 \mu \mathrm{g} \mathrm{mL}^{-1}$, and those showing a good evidence of antioxidant activity were tested over a range of concentrations to establish the $\mathrm{IC}_{50}$ (the concentration reducing DPPH absorbance by $50 \%$ ). It was calculated using the following formula:

$$
\left.\mathrm{I} \%=\left[\mathrm{A}_{\text {blank }}-\mathrm{A}_{\text {sample }}\right) / \mathrm{A}_{\text {blank }}\right] \times 100
$$

where: $A_{\text {blank }}$ is the absorbance of the control reaction (containing all reagents except the test compound), $\mathrm{A}_{\text {sample }}$ is the absorbance of the test compound. The antioxidant activity was calculated using the equation: \% inhibition $=100 \times(1-$ sample abs/control abs $)$.

\section{Cell-based antioxidant Assay}

Intracellular ROS production was detected using the non-fluorescent cell permeating compound, 2'7'-dichlorofluorescein diacetate (DCF-DA). ${ }^{20} 3$ T3-L1 cells were seeded at a density of $6 \times$ $10^{4}$ cells/well in a 96-well microplate in $100 \mu \mathrm{L}$ of growth medium. $24 \mathrm{~h}$ after seeding, the growth medium was removed and the wells were washed with PBS. Then, a $10 \mu \mathrm{mol} \mathrm{L}^{-1}$ solution of DCFH-DA dissolved in Hank's buffer $(100 \mu \mathrm{L})$ was added to wells and incubated for $30 \mathrm{~min}$ at $37{ }^{\circ} \mathrm{C}$ and $5 \% \mathrm{CO}_{2}$. The cells were washed first with $100 \mu \mathrm{L}$ PBS (Phosphate-buffered saline) and $100 \mu \mathrm{L}$ samples having different concentrations were added. The fluorescence was immediately measured at an excitation wavelength of $485 \mathrm{~nm}$ and emission wavelength of $520 \mathrm{~nm}$ over $60 \mathrm{~min}$, at $5 \mathrm{~min}$ intervals. Quercetin was used as positive controls of antioxidant activity.

\section{Anti-inflammatory in vitro assay}

Anti-inflammatory in vitro assay, ${ }^{21}$ with modifications, was performed with nitric oxide (NO*) production by $\mathrm{J} 774$ cells previously exposed at $1 \mu \mathrm{g} \mathrm{mL}^{-1}$ of lipopolysaccharide (LPS), assayed by 
measuring the accumulation of nitrite in the culture supernatant using Griess reaction. Briefly, after incubation of the cells $\left(1 \times 10^{6}\right.$ cells $\mathrm{mL}^{-1}$ ) with extracts in different concentrations of $6.25 ; 12.5 ; 25$ and $50 \mu \mathrm{g} \mathrm{mL}{ }^{-1}$, cells were incubated for $24 \mathrm{~h}$ with LPS $\left(1 \mu \mathrm{g} \mathrm{mL} \mathrm{m}^{-1}\right)$, at $37{ }^{\circ} \mathrm{C}$ in a $5 \% \mathrm{CO}_{2}$ incubator. Nitric oxide was measured as $\mathrm{NO}_{2}^{-}$in culture supernatant by reaction with Griess reagent. Absorbance of the reaction product was determined at $560 \mathrm{~nm}$ using a microplate reader. Sodium nitrite was used as a standard to calculate nitrite.

\section{Citotoxicity Assay}

The MCF-7 (human breast adenocarcinoma), SKMELL 19 (human melanoma), HCT116 (human colon adenocarcinoma) and the MRC-5 (human fibroblast) cell lines were grown in DMEM (Dulbecco's Modification of Eagle's Medium) medium supplemented with $10 \%$ fetal bovine serum, $2 \mathrm{mmol} \mathrm{L}^{-1}$ glutamine, $100 \mu \mathrm{g} \mathrm{mL}$ streptomycin and $100 \mathrm{U} \mathrm{mL}^{-1}$ penicillin, and incubated at $37^{\circ} \mathrm{C}$ with a $5 \%$ atmosphere of $\mathrm{CO}_{2}$. The cells were treated with the samples and the Alamar Blue ${ }^{\mathrm{TM}}$ Assay method. ${ }^{22}$ Briefly, after $24 \mathrm{~h}$ of culture, the extracts were individually dissolved in DMSO and added to each well (at well or final concentrations of $0,781-50 \mu \mathrm{g} \mathrm{mL}^{-1}$ ) and incubated for $72 \mathrm{~h}$. Doxorubicin $\left(5 \mu \mathrm{g} \mathrm{mL}^{-1}\right)$ was used as positive control. Negative controls (blanks) received the same amount of DMSO and had the same final DMSO concentrations as the samples $(0.1 \%)$. Two hours before the end of the incubations, $10 \mu \mathrm{L}$ of Alamar-Blue ${ }^{\mathrm{TM}}$ was added to each well. The fluorescent signal was monitored with a multiplate reader using a 530-560 $\mathrm{nm}$ excitation wavelength range and $590 \mathrm{~nm}$ emission wavelength. The fluorescent signal generated from the assay was proportional to the number of living cells in the sample, according to the specifications of the manufacturer.

\section{Hemolytic assay}

Hemolytic test was performed in 96 -well plates using a $2 \%$ mouse erythrocyte suspension in $0.85 \% \mathrm{NaCl}$ containing $10 \mathrm{mmol}$ $\mathrm{L}^{-1} \mathrm{CaCl}_{2},{ }^{23}$ The extracts were tested at a concentration of $2000 \mu \mathrm{g}$ $\mathrm{mL}^{-1}$. After incubation at room temperature for one hour followed by centrifugation, the supernatant was removed and the liberated hemoglobin was measured spectrophotometrically at $540 \mathrm{~nm}$.

\section{Statistical analyses}

Results are expressed as the means and standard deviations of triplicate measurements. Each experiment was performed at least three times. Differences between groups were assessed by one-way analysis of variance (ANOVA) followed by the Tukey post hoc test. A value of $\mathrm{P}<0.05$ indicated significance.

\section{RESULTS AND DISCUSSION}

The $C$. villosum fruit is widely consumed in Amazon region, with consequent huge amounts of husks (shells) and seeds residues been produced. These fruit parts are residues from amazon fruit industry without scientific studies to their biotechnological exploitation. A series of assays were perform aiming to promote a better understanding of extraction methods from shells, seeds and pulps that could result on high flavonoid and phenolic bioactive extracts.

\section{Phenolic compounds}

Shells, pulps and seeds of $C$. villosum were extracted with two different solvents: ethanol and ethanol:water (8:2). The total phenolic and total flavonoid contents from each one of the six extracts are described in Table 1. The total phenolic content varied from 147.45 to $4,917.91 \mathrm{mg}$ GAE/100 $\mathrm{g}$ of fresh weight. The highest amount of phenolic compounds was observed in the pulp extracts, with a similar result to total flavonoids. An amount of 4,917.91 $\pm 88.67 \mathrm{mg}$ GAE/100 g indicates that phenolic substances, similar to gallic acid, compose almost $5 \%$ of the extract. Most phenolic substances are not found in free-form in nature, but as esters or bounded to sugars and, mainly for this reason, many works have described hydroethanolic solvents suitable for extraction of phenolic substances, since they have a greater affinity with more polar aqueous solvents than organic solvents. ${ }^{24}$ In a previous study performed with piquiá fruit pulp, the highest values of phenolic compounds were found in the most polar solvent, ethanol / water and water extracts, compared with the less polar solvents, ethanol, ethanol / ethyl acetate extracts. ${ }^{6}$ In the current study, alcoholic extracts showed higher percentages of total phenolic compounds. The observed values for these extracts can be justified by the presence of aglycones, since they have more affinity with the ethanol, making it more selective and efficient in the extraction process.

Shell (or husks) extracts have also presented a high content of total phenolic and flavonoids, similarly to those observed in pulp extracts. According to the high content of bioactive substances observed at the present study, extracts from these shells could certainly be indicated as a valuable food supplement, as an example of biotechnological use. It is interesting to note that the number of phenolic substances found in the shell extracts was higher than that found in other fruit pulps that have been used as food by the population, such as bananas $(117.8 \pm 2.4 \mathrm{mg} \mathrm{GAE} / 100 \mathrm{~g})$, cashews $(118 \pm 3.7 \mathrm{mg} \mathrm{GAE} / 100 \mathrm{~g})$ and pulps of other tropical fruits. ${ }^{25,26}$

There is a positive correlation between the total phenolic and total flavonoids extracted, however it is non-linear. The highest amounts of flavonoids and phenolic compounds were obtained from the pulp extracts and the lowest were found in the seeds. The amounts of bioactive compounds detected pulp extracts were similar to the amount found previous studies, ${ }^{4}$ with total phenolics $4,623.4 \mathrm{mg}$ $\mathrm{GAE} / 100 \mathrm{~g}$ and total flavonoids $741.2 \mathrm{mg} \mathrm{CE} / 100 \mathrm{~g}$. With the addition of only $20 \%$ water, it was possible to observe significant differences in the two classes of biomolecules for the three types of extracts. For both total flavonoid and total phenolics there were a decrease by $18 \%$ and $11 \%$ with the addition of water, respectively. In the pulp extracts, the phenolic substances decreased $(5.2 \%)$ but a greater amount of flavonoids were extracted (16.7\%). In the seed extracts, the addition of water promoted the lipophobic effect resulting in a much higher amount of phenolic substances (143.4\%), and also caused a decrease in total flavonoids $(28.5 \%)$

\section{HPLC analysis}

The extracts that showed higher amounts of total flavonoid and phenolic compounds, obtained with both solvents were analyzed on reversed phase HPLC (figure 1). The analytical profiles were quite similar qualitatively, with several substances showing very close retention times. Results from the HPLC analysis of the ethanol and hydroethanolic extracts revealed similar chromatographic profiles to shell and pulp extracts. Chromatograms were qualitatively identical but quantitatively different, with different amounts of gallic and ellagic acids. The profile of phenolic compounds was similar to that found in other studies using pulp, where the main compounds were the ellagic deoxyhexoside, gallic and ellagic acids. ${ }^{6}$ These last two substances were identified by UV spectra and retention time comparison of standards by HPLC (Figure 1B).

The pulp extracts showed higher amounts of gallic and ellagic acids and a similar profile in both extracting solvents. The quantities in $\mu \mathrm{g} \mathrm{g}^{-1}$ of gallic acid were 1,712.62 \pm 56.79 for shell extracts 

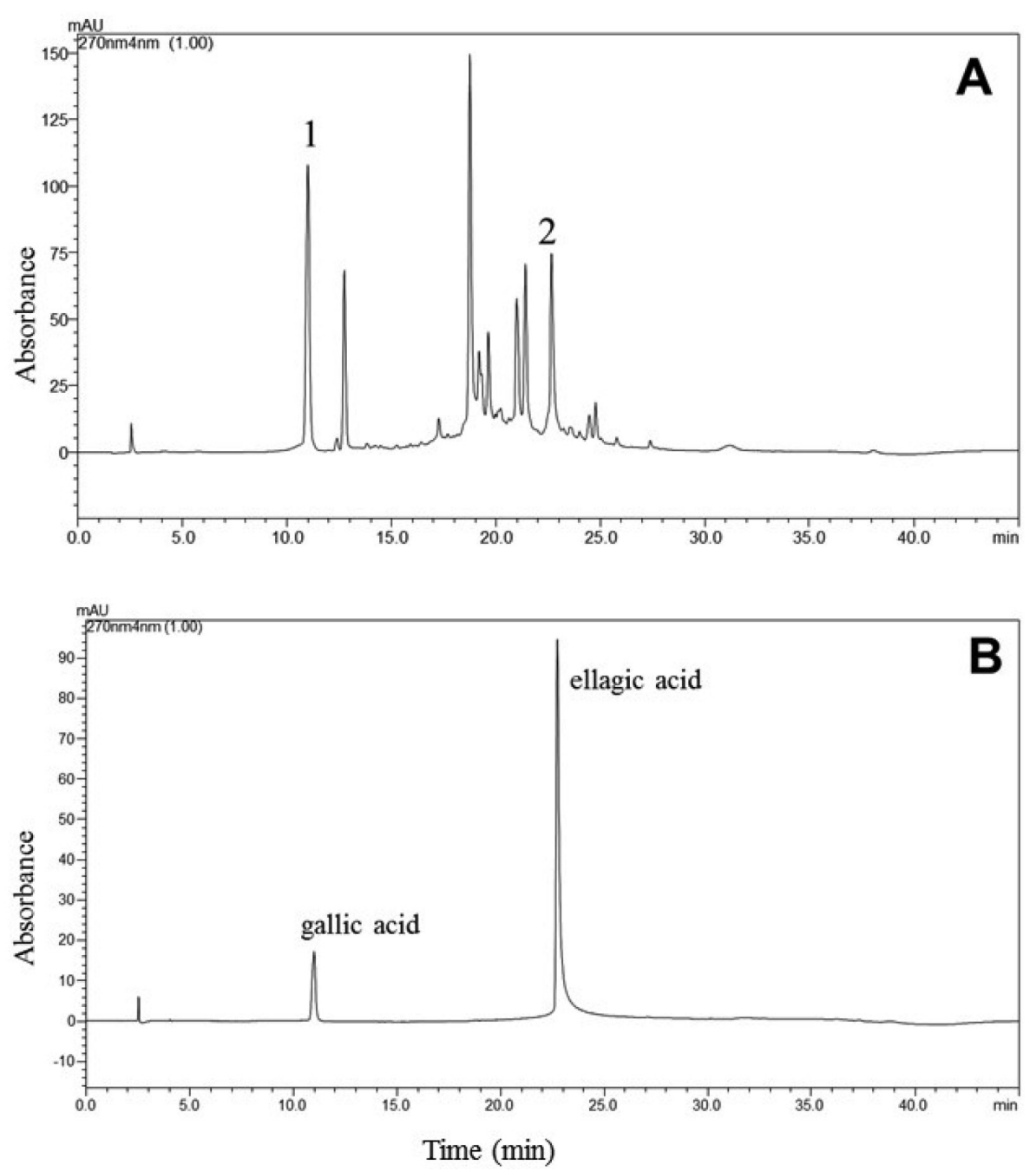

Figure 1. HPLC chromatograms of (A) hydroethanolic extract of $C$. villosum pulp and (B) mixture of gallic and ellagic acids standards

obtained with ethanol and 1,642.06 \pm 20.67 for hydroethanolic extracts. In the pulp extracts, the amounts were 2,706.67 \pm 148.75 and $3,507.78 \pm 110.10$ in ethanol and hydroethanolic extracts, respectively. The amounts of ellagic acid observed in shell extracts obtained in ethanol was $1,873.63 \pm 63.12$, and 1,133.01 \pm 67.25 was the amount of this substance at hydroethanolic extract. At pulp extracts obtained in ethanol $1,148.49 \pm 78.36$, with $1,791.63 \pm 51.90$ of ellagic acid detected at hydroethanolic extract. The amounts of gallic and ellagic acids in pulp extracts were similar to the values reported in other studies for the pulp using hydroethanolic solvent: gallic acid: $1,150 \pm 20.12 \mu \mathrm{g} \mathrm{g}^{-1}$ and $2021 \pm 168.62 \mu \mathrm{g} \mathrm{g}^{-1}$ of ellagic acid.

The amount found for both phenolic compounds was greater than that described for the extraction in medium polarity solvents (ethyl acetate and mixture of ethanol: ethyl acetate). ${ }^{6}$ In a study by Magid et al. ${ }^{3}$ the chromatographic profiles of the triterpene fractions of shell and pulp extracts were similar, differing in the amount of substances present. These results corroborate those found for the phenolic fraction in this work. Thus, it appears that the shell and pulp extracts of the fruit show similar chemical composition of major substances, but in different quantities.

\section{Antioxidant activity}

Extracts with high levels of bioactive compounds from accessible natural sources are of high interest for the food, pharmaceutical and cosmetic industries. The results obtained for total phenolics, total flavonoid content and the already known antioxidant activities from the substances identified by HPLC and UV spectra strongly indicates that the extracts show antioxidant activities. Several studies correlate total phenolic and total flavonoids with DPPH and ABTS activities. ${ }^{27}$ The $C$. villosum extracts were analyzed on DPPH and ABTS assays in comparison with quercetin and gallic acid. The result obtained in this study is presented at Table 1, with high scavenging potency for radical compounds.

The scavenging capacity of all extracts seemed to be closely dependent on the phenolic compound contents. This relationship is described in other studies, ${ }^{27,28}$ wherein the amount of phenolic and antioxidant activity also was proportional. The antioxidant activity of shell and pulp extracts showed an antioxidant activity similar to the standard, confirming earlier work with $C$. villosum pulp extract. Wherein it showed high ability to scavenge other reactive species: oxygen (ROS) and nitrogen (RNS). ${ }^{6}$ It was found that the stabilization of the radicals is proportional to the amount of phenolic substances and related to the chemical structure of these substances. Phenolic compounds are characterized by the presence of an aromatic ring substituted by at least one hydroxyl group. Thus, due to the resonance of the aromatic ring, phenolic compounds have higher retention capacity.

Important antioxidants were identified in materials that were initially discarded, such as resveratrol, some studies being performed with industrial and agro-industrial residues in Brazil. ${ }^{29}$

High antioxidant capacity of extracts from non-edible parts of C. villosum are compared and even higher to other Brazilian fruits, 
Table 1. Antioxidant activity and total phenolic and flavonoids from C. villosum fruit extracts

\begin{tabular}{|c|c|c|c|c|c|}
\hline Solvent & Sample & $\begin{array}{l}\text { Total phenolics } \\
\text { (mg GAE/100g) }\end{array}$ & Total flavonoids (\%) & $\mathrm{DPPH}\left(\mu \mathrm{g} \mathrm{mL} \mathrm{m}^{-1}\right)$ & $\operatorname{ABTS}\left(\mu \mathrm{g} \mathrm{mL}^{-1}\right)$ \\
\hline & Shell & $4523.39 \pm 105.19$ & $4.59 \pm 0.12$ & $7.81 \pm 0.34$ & $3.93 \pm 0.12$ \\
\hline \multirow[t]{3}{*}{ Ethanol } & Pulp & $4917.91 \pm 88.67$ & $4.91 \pm 0.27$ & $7.95 \pm 0.27$ & $4.34 \pm 0.29$ \\
\hline & Seed & $147.45 \pm 9.63$ & $3.55 \pm 0.14$ & $97.48 \pm 1.15$ & $41.07 \pm 1.42$ \\
\hline & Shell & $4153.13 \pm 39.17$ & $4.09 \pm 0.16$ & $8.52 \pm 0.37$ & $5.45 \pm 0.04$ \\
\hline \multirow[t]{5}{*}{ Ethanol:water (8:2) } & Pulp & $4665.59 \pm 23.73$ & $5.73 \pm 0.16$ & $8.48 \pm 0.49$ & $4.43 \pm 0.06$ \\
\hline & Seed & $350.79 \pm 12.03$ & $2.54 \pm 0.16$ & $62.64 \pm 2.42$ & $29.80 \pm 0.24$ \\
\hline & \multicolumn{2}{|c|}{ Ellagic acid } & & $4.71 \pm 0.21$ & $4.01 \pm 0.01$ \\
\hline & \multicolumn{2}{|c|}{ Gallic acid } & & $3.50 \pm 0.24$ & $3.26 \pm 0.03$ \\
\hline & \multicolumn{2}{|c|}{ Standard } & & $5.06 \pm 0.11^{\mathrm{A}}$ & $5.57 \pm 0.15^{\text {в }}$ \\
\hline
\end{tabular}

Standard: $\mathrm{A}=$ quercetin; $\mathrm{B}=$ trolox.

like of Brazilian blackberry, red raspberry, strawberry, blueberry and sweet cherry fruits cupuassu, bacuri, uxi, murici, ${ }^{30}$ being lower than that found in samples of assai.$^{31}$ However, there are no studies involving the quantification of phenolic compounds and antioxidant activity of shell and seed extracts from $C$. villosum. It was found that this plant part is currently discarded by the population, becoming an organic waste, but showed a large amount of bioactive substances. The possible use of these materials may increase interest and encourage biotechnological studies aimed at full utilization of this fruit, and also further studies on the antioxidant activity, since this has been ascribed to various pathologies.

The extracts from shell, pulp and seeds were also assessed for the antioxidant potential in cell-based assay. Few data are available in literature on the antioxidant activity using cell models of Amazonian fruits, and the first evaluation in piquiá pulp and shell extracts. The extracts were tested at a single concentration of $20 \mu \mathrm{g} \mathrm{mL}^{-1}$ and showed antioxidant activity of $70.69 \pm 2.77 \%$ (seed), $79.89 \pm 6.50$ (shell) and $79.48 \pm 8.6$ (pulp) (Figure 2).

The results observed in cell experiments are consistent with the in vitro activities for DPPH and ABTS radical and proportional to the amount of phenolic substances. The percentage of oxidation inhibition of pulp and seed extracts showed a significant difference between the extraction solvents. The hydroethanolic seeds extract showed an activity three times higher $\left(0.78 \mu \mathrm{g} \mathrm{mL}^{-1}\right)$ than the quercetin standard $\left(3.12 \mu \mathrm{g} \mathrm{mL}^{-1}\right)$, while the ethanol extract did not show significant result for the studied concentration. The same effect was found for pulp extracts, where the hydroethanolic extract showed higher antioxidant activity when compared to those from the ethanol extract.

The results from the antioxidant activity of seed and pulp extracts demonstrate the diversity of substances responsible for the activity tested. The primarily responsible for the antioxidant capacity of C. villosum pulp extracts are recognized to be phenolic substances,
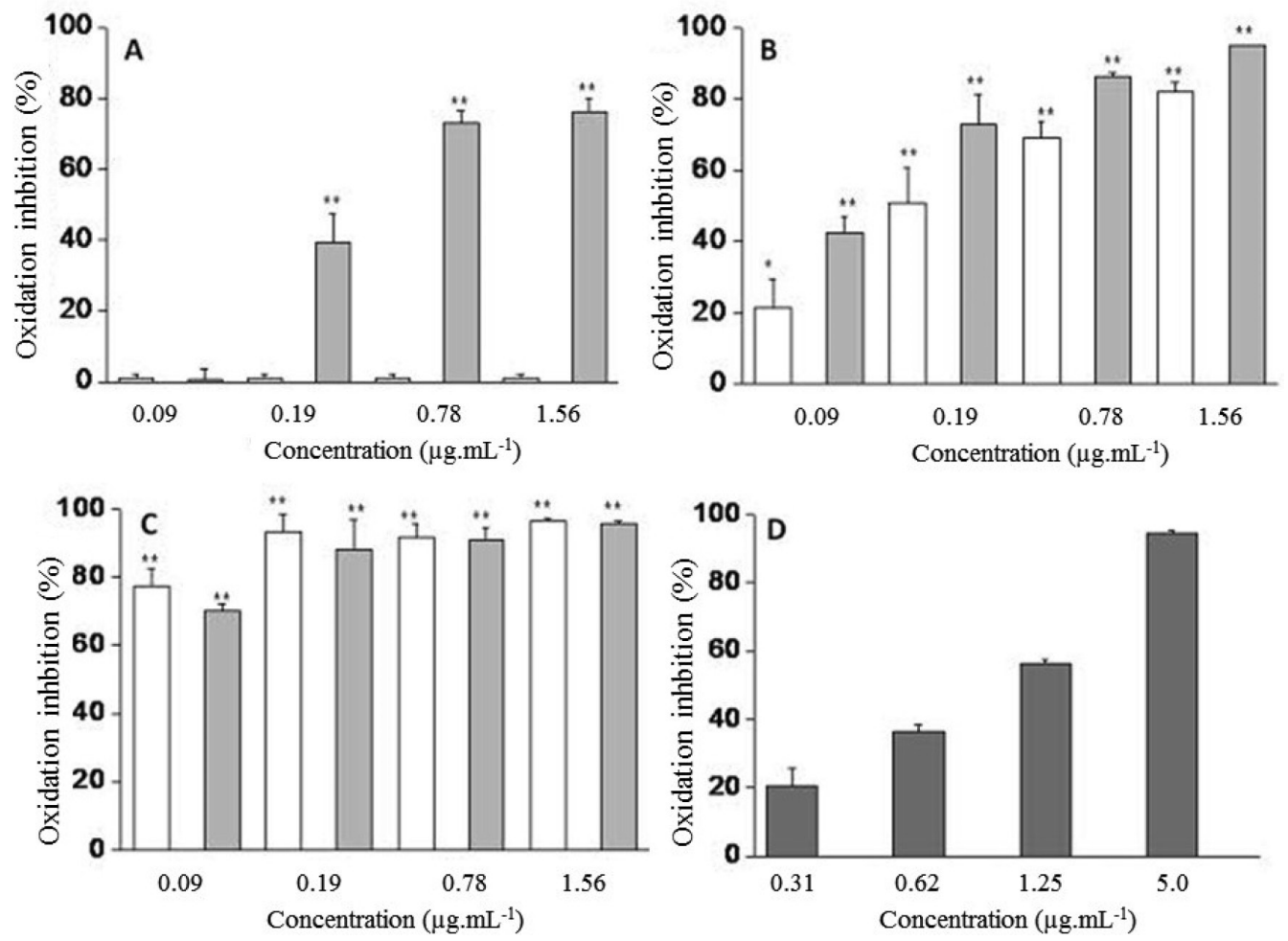

Figure 2. Antioxidant activity the C. villosum extracts ethanol (white) and hydroethanolic (gray) - (A) Seed; (B) Pulp; (C) shell extracts; (D) Control standards quercetin $\left(0.09-1.56 \mu \mathrm{g} . \mathrm{mL}^{-1}\right)$ in the $3 T 3 \mathrm{~L} 1$ mouse embryonic fibroblast cell line. The antioxidant activity values are the mean \pm S.D from three independent experiments. Significance was determined using Student's-t-test ( $* p<0.05 ; * * p 0.01$ compared to quercetin) 
mainly gallic and ellagic acid. ${ }^{4,6}$ However, in seed extracts, these phenolic compounds were not detectable and their content was minimal $(35.09 \pm 01.03$ and $14.75 \pm 0.63 \mathrm{mg} \mathrm{GAE} / \mathrm{g})$, compared with pulp extracts. Thus, the high antioxidant capacity observed at seed extracts must be assigned to other classes of substances, such as carotenoids, tocopherols and fatty acids, which are antioxidant substances commonly found in seeds. The shell extracts showed a similar profile in both extracting solvents. Both ethanol and hydroethanol extracts showed high antioxidant activity, with an activity of $90 \%$ in the low concentrations $\left(0.78 \mu \mathrm{g} \mathrm{mL}^{-1}\right)$. The ethanol extract showed the highest percentage of total phenolics and ellagic acid, what may be associated with the best antioxidant result observed.

The search for antioxidant agents persists due to the side effects caused by the use of synthetic antioxidants, such as toxicity, carcinogenicity, increased liver weight and significant proliferation of the endoplasmic reticulum. It is presumed that antioxidant mechanisms such as those found in this work are able to neutralize free radicals by oral or topical administration. Thus, they may protect skin from oxidative damage and have an important role in the prevention of diseases and aging process.

\section{Anti-inflammatory activity}

Nitric oxide $\left(\mathrm{NO}^{*}\right)$ and free radicals are present in inflammatory processes and they are monitored as a tool to analyze substances having anti-inflammatory activity. Free radicals liberated from phagocyte cells are important in inflammatory processes because they are implicated in the activation of nuclear factor $\mathrm{jB}(\mathrm{NF}-\mathrm{jB})$, which induces the transcription of inflammatory cytokines and COX $-2 .^{32}$ In this study, measurement of NO (expressed such as nitrite) of $\mathbf{J 7 7 4}$ macrophages stimulated with LPS was used as indicative of anti-inflammatory potential in vitro tests. The inhibition of $\mathrm{NO}^{\bullet}$ production is correlates with a possible ability of the extract to reduce the inflammatory process. To evaluate the effect on the production of oxide, extracts were tested at concentrations of 25 , 10 and $5 \mu \mathrm{g} \mathrm{mL}^{-1}$. (Figure 3).
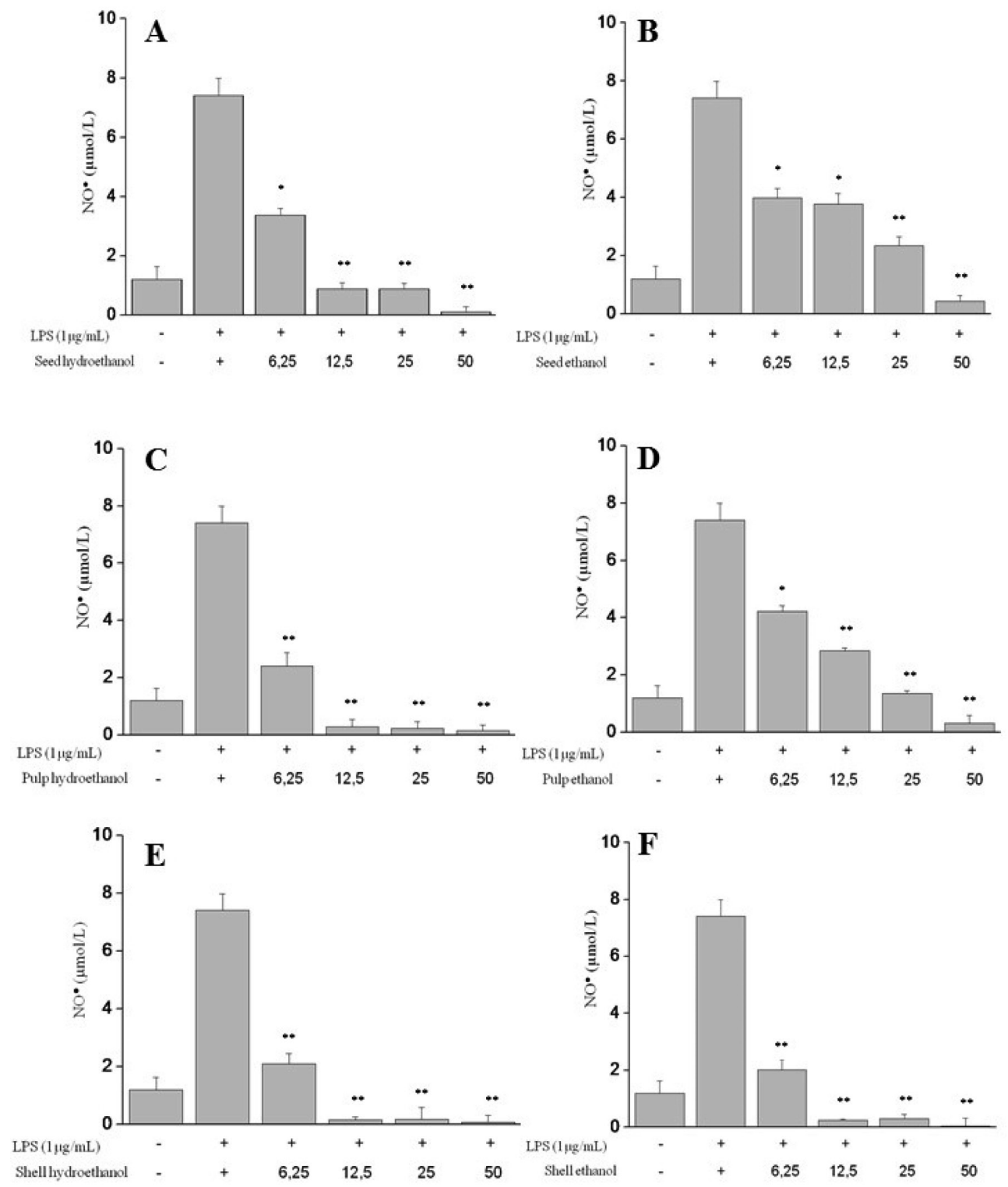

Figure 3. Effect of the C. villosum extracts on NO production in LPS-stimulated J774 cells. (A) Seed (hydroethanolic); (B) Seed (ethanol); (C) Pulp (hydroethanolic); (D) Pulp (ethanol); (E) Shell (hydroethanolic); (F) Shell (ethanol). Production of NO was assayed in culture supernatants of macrophages stimulated with LPS $\left(1 \mu \mathrm{g} \mathrm{mL} L^{-1}\right)$ for $24 \mathrm{~h}$ in the presence of the extracts $\left(6.25-50 \mu \mathrm{g} \mathrm{mL}^{-1}\right)$. The nitrite values are the mean \pm S.D from three independent experiments. Significance was determined using Student's-t-test $(* p<0.05 ; * * p<0.01$ compared to LPS). Abbreviations: LPS, Lipopolysaccharide; NO, nitric oxide 
C. villosum extracts showed high inhibition at a low concentration. The shell extracts showed the best results. In both extractions, alcoholic and hydroethanolic, the results were similar for $\mathrm{NO}^{\circ}$ inhibition, at a concentration of $12.5 \mu \mathrm{g} \mathrm{mL} \mathrm{m}^{-1}$ it inhibited almost $100 \%$ of nitric oxide production. The pulp, however, showed selective result, based on the solvent extractor. For the pulp hydroethanolic extract, concentrations from $2.5 \mu \mathrm{g} \mathrm{mL}^{-1}$ inhibited almost $100 \%$ of nitric oxide production. While this result can only be verified in concentration above $50 \mu \mathrm{g} \mathrm{mL}^{-1}$ in ethanolic extract. Similar to the antioxidant analysis in cell, in the ability to inhibit $\mathrm{NO}^{\bullet}$ only the seed hydroethanolic extract showed the ability to inhibit at a concentration of $12.5 \mu \mathrm{g} \mathrm{mL}^{-1}$ around $72.51 \pm 1.65 \%$. The seed extract in ethanol showed low capacity compared with other parts, pulp and shell, requiring a high concentration so to inhibit the radical. In general, the results of antioxidant activity and anti-inflammatory ability showed some correlations, especially between shell extracts obtained in both ethanolic and hydroethanolic solvents. Such result indicates a potential source for more deep studies with others inflammation mechanisms. Similar results were obtained with $C$. coriaceum seed extracts that were capable of reducing inflammation in various types of edema. The seeds of $C$. coriaceum are rich in lipid substances and the presence of fatty acids and their methyl esters are primarily responsible for the anti-inflammatory activity of the extract. ${ }^{11}$

\section{Cytotoxicity}

C. villosum extracts were evaluated for their cytotoxicity against tumoral human cells (SKMELL19, MCF-7 and HCT116) and non-tumoral (MCR-5) using the antitumor drug doxorubicin as the positive control. At a concentration of $50 \mu \mathrm{g} \mathrm{mL}^{-1}$, after 72 $\mathrm{h}$ of treatment, the ethanol and hydroethanolic extracts did not exhibit cytotoxicity to these human cell lines $\left(\mathrm{IC}_{50}>50 \mu \mathrm{g} \mathrm{mL} \mathrm{m}^{-1}\right)$. The results of doxorubicin (positive control) are much lower than all the tested extract concentrations. At $50 \mu \mathrm{g} \mathrm{mL} \mathrm{m}^{-1}$ any cell line has reached $50 \%$ cytotoxicity. To verify whether extracts cytotoxicity is related to membrane disruption, the ability to induce lyses of mouse erythrocytes was investigated and no membrane damage was found. This demonstrates that these extracts have low cytotoxicity, suggesting that the compounds do not have hemolytic activity and do not cause damage to cell membranes.

The test of hemolysis in erythrocytes of mice in vitro is an important tool for assessing the toxicity of biological samples and the cytotoxicity evaluation provides a parameter in the safe use of these extracts. The low cytotoxicity of a food is an important factor for food security. Considering that many fruits are used by the cosmetic and food industries, the negative results in cytotoxicity assay characterize the condition of harmless. ${ }^{33}$

\section{CONCLUSIONS}

The current study characterized some important biological activities of $C$. villosum fruit extracts and allowed the detection and quantification of two previously identified phenolic compounds. The low toxic potential observed is of high importance for the development of biotechnology products with antioxidant and anti-inflammatory activities.

\section{ACKNOWLEDGEMENT}

The authors are grateful to the Conselho Nacional de Desenvolvimento Científico e Tecnológico (CNPq) and Fundação de Amparo à Pesquisa do Estado do Amazonas (FAPEAM) for funding this research. KKLY received a grant from FAPEAM.

\section{REFERENCES}

1. Marx, F.; Andrade, E. H, A.; Maia, J. G.; Z. Lebensm.-Unters. -Forsch. A 1997, 204, 442.

2. Grenand, P.; Moretti, C.; Jacquemin, H.; Prévost, M. F.; Pharmacopées traditionnelles en Guyane, Créoles, Wayasi, Palikur, $1^{\text {th }}$ ed., IRD: Paris, 2004.

3. Magid, A. A.; Voutquenne-Nazabadioko, L.; Harakat, D.; Pouny, I.; Caron, C.; Moretti, C.; Lavaud, L.; J. Nat. Prod. 2006, 69, 919.

4. Barreto, G. P. M.; Benassi, M. T.; Mercadante, A. Z.; J. Braz. Chem. Soc. 2009, 20, 1856.

5. Magid, A. A.; Voutquenne-Nazabadioko, L.; Harakat, D.; Moretti, C.; Lavaud, L.; J. Nat. Prod. 2008, 71, 914.

6. Chisté, R. C.; Mercadante, A. Z.; J. Agr. Food Chem. 2012, 60, 5884.

7. Xavier, W. K. S.; Medeiros, B. J.; Lima, C. S.; Favacho, H. A.; Andrade, E. H. A.; Araújo, R. N. M.; Santos, L. S.; Carvalho, J. C. T.; J. Appl. Pharm. Sci. 2011, 1, 62.

8. Almeida, M. R.; Darin, J. D.; Hernandes, L. C.; Aissa, A. F.; Chisté, R. C.; Mercadante, A. Z.; Antunes, L. M. G.; Bianchi, M. L.; Plant Foods Hum. Nutr. (N. Y., NY, U. S.) 2012, 67, 171.

9. Almeida, M. R.; Aissa, A. F.; Gomes, T. D. U. H.; Darin, J. D. C.; Chisté, R. C.; Mercadante, A. Z.; Antunes, L. M. G.; Bianchi, M. L. P.; J. Med. Food 2013, 16, 268.

10. Batista, J. S.; Silva, A. E.; Rodrigues, C. M. F.; Costa, K. M. F. M.; Oliveira, A. F.; Paiva, E. S.; Nunes, F. V. A.; Olinda, R. G.; Arq. Inst. Biol. 2010, 77, 441 .

11. Saraiva, R. A.; Araruna, M. K.; Menezes, K. D.; Leite, G. O.; Costa, J. G.; Rocha, J. B.; Tomé, A. R.; Campos, A. R.; Menezes, I. R.; J. Ethnopharmacol. 2011, 136, 504.

12. Lowenstein, C. J.; Hill, S. L.; Lafond-Walker, A.; Wu, J.; Allen, G.; Landavere, M.; Rose, N. R.; Herskowitz, A.; J. Clin. Invest. 1996, 97, 1837.

13. Souza, M. A. A.; Souza, S. R.; Veiga Junior, V. F.; Cortez, J. K. P. C.; Leal, R. S.; Dantas, T. N. C.; Maciel, M. A. M.; Rev. Bras. Farmacogn. 2006, 16, 599 .

14. Vasconcelos, K. R. F.; Rocha, W. C.; Veiga Junior, V. F.; Bandeira, M. F. C. L.; Rev. Bras. Farmacogn. 2008, 18, 733.

15. Yamaguchi, K. K. L.; Lima, E. S.; Santarém, L. S.; Lamarão, C. V.; Veiga Junior, V. F.; Sci. Amaz. 2016, 6, 109.

16. Singleton, V. L.; Rossi, J. A.; Am. J. Enol. Vitic. 1965, 16, 144

17. Chang, C. C.; Yang, M. H.; Wen, H. M.; Chern, J. C.; J. Food Drug Anal. 2002, 10, 178 .

18. Re, R.; Pellegrini, N.; Proteggent, A.; Pannala, A.; Yang, M.; RiceEvans, C.; Free Radic. Biol. Med. 1998, 26, 1231.

19. Molyneux, P.; J. Sci. Technol. 2004, 26, 211.

20. Wolfe, K. L.; Liu, R. H.; J. Agric. Food Chem. 2007, 55, 8896.

21. Green, L. C.; Wagner, D. A.; Glogowski, J.; Skipper, P. L.; Wishnok, J. S.; Tannenbaum, S. R.; Anal. Biochem. 1982, 26, 131.

22. Ahmed, S. A.; Gogal, J. R. R. M.; Walsh, J. E.; J. Immunol. Methods 1994, 15, 211

23. Jimenez, P. C.; Fortier, S. C.; Lotufo, T. M. C.; Pessoa, C.; Moraes, M. E. A.; Moraes, M. O.; Costa-Lotufo, L. V.; J. Exp. Mar. Biol. Ecol. 2003, 287, 93.

24. Rockenbach, I. I.; Silva, G. L.; Rodrigues, E.; Kuskoski, E. M.; Fett, R.; Cienc. Tecnol. Aliment. 2008, 28, 238.

25. Rufino, M. S. M.; Alves, R. E.; Brito, E. S.; Pérez-Jiménez. J.; SauraCalixto, F.; Mancini-Filho, J.; Food Chem. 2010, 121, 996.

26. Clerici, M. T. P. S.; Carvalho-Silva, L. B.; Food Res. Int. 2011, 44, 1658.

27. Li, X.; Wu, X.; Huang, L.; Molecules 2009, 14, 5349.

28. Santos, P. M.; Almeida, P. D. O.; Lima, E. S.; Moraes, M. O.; Costa, P. M.; Meira, A. S., Ó Pessoa, C.; Valente, L. M. M.; Veiga Junior, V. F.; Quim. Nova 2014, 37, 89. 
29. Oliveira, A. C.; Valentim, I. B.; Silva, C. A.; Henriques Bechara, E. J.; De Barros, M. P.; Mano, C. M.; Goulart, M. O. F.; Food Chem. 2009, 115,469 .

30. Souza, V. R.; Pereira, P. A. P.; Silva, T. L. T.; Lima, L. C. O.; Pio, R.; Queiroz, F.; Food Chem. 2014, 156, 362.

31. Yamaguchi, K. K. L..; Pereira, L. F. R.; Lamarão, C. V.; Lima, E. S.; Veiga Junior, V. F.; Food Chem. 2015, 179, 137.
32. Szabó, C.; Thiemermann, C.; Vane, J. R.; Biochem. Biophys. Res. Commun. 1993, 196, 825.

33. Pape, W. J.; Pfannenbecker, U.; Argembeaux, H.; Bracher, M.; Esdaile, D. J.; Hagino, S.; Kasai, Y.; Lewis, R. L.; Toxicol. In Vitro 1999, 13, 343. 